Vol. 9 No.1 January 2020

P-ISSN: 2301-9913, E-ISSN: 2597-9132

DOI: http://dx.doi.org/10.31000/globish.v7i2

\title{
An Analysis Of The Illocutionary Acts On Donald Trump's Presidential Candidacy Speech
}

\author{
${ }^{1}$ Desinta Larasati, ${ }^{2}$ Arjulayana, ${ }^{3}$ Cut Novita Srikandi \\ 1,2,3 English Study Program- University of Muhammadiyah Tangerang \\ Corresponden Email: desintalarasati19@gmail.com,arjulayana@umt.ac.id
}

\begin{abstract}
Learning language will also relate to speech act. When a speaker produce an utterance as well as utilize it to perform an action, it means that the speaker practices speech acts. In another hand, speech acts can be defined as an utterance used by speaker to perform an action. Speech acts are divided into three such as locutionary act, illocutionary act, and perlocutionary act. One of them is illocutionary act. The illocutionary act refers to what someone does in saying something. In this act, illocutionary force is the speaker's intent addressed to hearer. This research is aimed to find the types of illocutionary acts and identifying about how utterances in the Donald Trump's speeches are able to be included into certain type of illocutionary acts be based on Searle's theory. This research is designed in descriptive qualitative. The data is collected by documentation. The primary data are taken from two transcripts of Donald Trump's presidential candidacy speeches. While the secondary data are related theories obtained from literary books and journals. The procedure of analyzing the data starts by finding out the types of illocutionary acts in the Donald Trump's presidential candidacy speeches by using the illocutionary acts' classifications proposed by Searle (1969). After that, the researcher also identifies about the different frequency of illocutionary acts appearances and the dominant illoctionary acts appeared in the Donald Trump's presidential candidacy speeches. The finding shows that the type of illocutionary acts found in the Donald Trump's speeches were assertive, commissive, expressive, and directive. Eventhough the types of illocutionary acts found in Donald Trump's speeches were exactly the same, but they were different in the frequency of appearance. Donald Trump produced mostly assertive type of illocutionary acts and also asserting category of illocutionary type in both of the speeches. Moreover, some utterances are included into assertive type of illocutionary acts due to the fact that they have a suitability with the explanation of assertive type of illocutionary acts proposed by Searle.
\end{abstract}

Keywords: Illocutionary Acts, Speech Acts, Presidential Candidacy Speeches.

\section{INTRODUCTION}

Language plays a crucial role in human's life since it is a medium in delivering messages such as ideas, emotions, and thoughts by uttering them from a speaker to the hearer by using gestures, sounds, or signals for many different reasons and intentions. Language can be defined as the method for human communication, either in spoken or written form, consisting of the use of words in a structured and conventional way. There are two types of communication. They are verbal communication which uses words as the element in communicating messages and nonverbal which uses gestures, facial expressions, signals, body movements, eye contacts, and general appearances in communicating messages which are done by the speaker to the hearer.

In their research, Praditya, et. al. (2014, p.2) stated that the speech act theory reveals about how speakers express and deliver their purposes by using utterances. So, people using language in communicating their ideas or emotions means that they produce utterance. When people produce utterance, at the same time, they also do some actions such as requesting, asking, commanding, refusing, arguing, informing, and so on. These actions are included into speech acts.

Received July 20, 2019; Revised August 20, 2019 ; Accepted September 15, 2019 
ISSN: 2301-9913, E-ISSN: 2597-9132

DOI: http://dx.doi.org/10.31000/globish.v7i2

When performing speech act with another person, it means the speaker is conveying his or her ideas to another with particular intentions and purposes. Austin (1962, p.108) points out that there are three kinds of acts performing simultaneously while uttering a sentence, those are a locutionary act, illocutionary act, and perlocutionary act (Wardani, 2011, p.3). Different types of speech acts shows that there are many various communicative intentions while producing utterances.

Speech is also important in politics due to the fact that many of politics' activites performed by politicians utilize language. For instance, the activities such as political campaigns, speeches, written texts, and broadcasts are used to inform and instruct society about issues that should be considered as an importance. One of the famous politicians is Donald Trump. He is the political figure in the United States as well as the current president of the United States who won over voters in the United States general election in 2016. President is the highest position in a country, therefore the president needs to link and have a good relationship with a wide variety of people in the country.

One of ways to achieve this is through doing speech in order to convey ideas and deliver messages to people. In this research, the researcher uses two different presidential candidacy speeches of Donald Trump. Due to the fact that both of the speeches were done in different condition and situation, some differences of illocutionary acts might appear in both of the speeches. Therefore, this research is going to be the analysis of the illocutionary acts in Donald Trump's presidential candidacy speeches.

\section{REVIEW OF RELATED LITERATURE}

1. Pragmatics

Pragmatics is one of linguistic branches which is concerned with meaning. According to Fraser (1990), pragmatic meaning has something to do with the speaker's communicative intention (Schriffin, 2001, p.59). It means that speaker's utterance directly relates to the pragmatic meaning which consists of communicative intention of the speaker. In line with Fraser's statement, Yule (1996, p.46) states that pragmatics is the study of meaning communicated by speaker or writer and interpreted by listener or hearer (Usman, 2017, p.1213). When conveying ideas to other, the speaker also tries to communicate the meaning consisted in the utterance. Since then, there is a speaker's expectation that is expected to be interpreted and responded correctly by the hearer. In addition, Mey (2001) in his book entitled "Pragmatics: an Introduction", pragmatics is the study about human language use. It studies about how the way people use their language in communication so that it will affect the hearer or reader with the utterances uttered by speaker or writer and it is also determined by the condition of society. From those definitions and illustrations above about pragmatics, we can clearly understand that pragmatics is a study of intended meaning contained in the speaker's utterance related to its context. It deals with how people use language and why they use language in a particular way.

2. Speech Acts

According to Yule (1996), as a branch of linguistics, pragmatics, has many scopes such as deixis, presupposition, cooperative principle, implicature, and speech acts (Saputro, 2015, p.16). As stated before that one of scopes of pragmatics is speech acts, so when we study the speech act means that we also study the utterance. Utterances produced by speaker often in the form of commanding, informing, promising, greetings apologizing, persuading, asking, congratulating, warning, advising and any other declarations. Those expressions also carry out actions such as to inform, to promise, to greet, to persuade, to apologize, to ask, to warn, to give advice, and to express feeling and delivering messages. And these acts are known as speech acts.

3. Illocutionary Acts

An Analysis Of The Illocutionary Acts On Donald Trump's

Presidential Candidacy Speech

${ }^{1}$ Desinta Larasati, ${ }^{2}$ Arjulayana, ${ }^{3}$ Cut Novita Srikandi 
ISSN: 2301-9913, E-ISSN: 2597-9132

DOI: http://dx.doi.org/10.31000/globish.v7i2

(Asadu, 2013, p.83) states that the illocutionary act refers to what someone does in saying something. In this act, the illocutionary force is the speaker's intent addressed to hearer. Illocutionary acts deal with the speaker's intention while communicating with the hearer. Searle (1969) categorizes the illocutionary acts into five types, such as: a) Assertives, b) directives, c) commissives, d) expressives, and e) declarations (Dylgjeri, 2017, p.21-22). The elaboration of each category is presented as follows:

a) Assertives

Assertives refer to statements that describe a state of affairs in the world which could be true or false. There are different kinds of assertive category such as asserting, describing, claiming, complaining, and informing. Assertive acts are performed by speakers or writers to tell what they know or believe. Moreover, assertive acts deal with facts, so it means that while performing representative acts, the speakers or writers make the words fit with the world or belief. The utterance "Today is Monday" is an illustration of assertive statement due to the fact that the word 'today' signs that the previous statement uses Simple Present Tense and is a fact. Moreover, the previous utterance includes into the asserting category of illocutionary type because the sentence is a statement.

b) Directives

The illocutionary point or purpose of this category is that the speaker tries to make hearer or addressee performing an action mentioned in the utterance uttered by the speaker. There are different kinds of directive category such as commanding, forbidding, inviting, requesting, suggesting, ordering, and asking. The utterance "would you mind for coming back here later?" is an illustration of asking category in the directive type of illocutionary acts due to the fact that the utterance uttered by the speaker causes the hearer to do an action.

c) Commisives

The illocutionary point or purpose of commisive category is to cause the speaker doing something in the future. There are different kinds of this category such as promising, vowing, offering, and threatening. The utterance "I promise to take care of you in the whole of my life" which is usually spoken in the wedding ceremony is included in the promising category of the commissive type of illocutionary acts due to the fact that the previous utterance will cause hearer to do something in the future.

d) Expressives

The illocutionary points of this category is to express the speaker's feeling about the situation. In another hand, expressive refers to acts that are performed to express a psychologcal state of the speaker. Statement of pleasure, pain, dislike, joy, and sorrow can be categorized into this act. In addition, there are some expressive verbs consisting in this act such as thanking, congratulating, apologizing, condoling, praising, and blaming. The utterance "Thank you so much for the savory dinner" is included into the thanking category of the expressive type of illocutionary acts due to the fact that the phrase 'thank you' signs that the speaker wants to express his or her gratitude to the hearer.

e) Declaratives

Declaratives refer to an illocutionary act that brings into existence the state of affairs of something new such as status, circumstance, and so on. In another hand, particular utterance produced in a particular context may be able to change the condition or status immediately. Since this act may cause a changing of condition or status toward something, the speaker must have specific institutional roles and there must be a specific context as well. There are some kinds of this category such as Christening or baptizing, naming, dismissing, resigning, appointing, and sentencing. The utterance "I declare you to be a husband and wife" is included in the declarative type of illocutionary acts due to the fact that the utterance cause changing into marital status for both man and woman.

An Analysis Of The Illocutionary Acts On Donald Trump's

Presidential Candidacy Speech

${ }^{1}$ Desinta Larasati, ${ }^{2}$ Arjulayana, ${ }^{3}$ Cut Novita Srikandi 
ISSN: 2301-9913, E-ISSN: 2597-9132

DOI: http://dx.doi.org/10.31000/globish.v7i2

METHODOLOGY

This research uses the descriptive method with the qualitative approach. According to Sudaryanto (1993, p.62), the method is able to figure out as accurate as possible toward the object being analyzed about an individual, state of language, and social symptomps in particular groups. While the descriptive suggests that the research writing which is conducted based on facts or phenomena emphirically alive in the speaker so that the generating data are in the form of language or explanation in its natural form (Rahma, 2013, p.16).

Here are some points of processing the techniques of data analysis that were used by the researcher in concucting this research according to the book of research writing proposed by University of Muhammadiyah Tangerang (2018. P.88): (1) Data Reduction. In data reducion, the writer reduces the data by summarizing and focusing the data into some steps which are needed for the research. (2) Data Presentation. In this process, the researcher is going to show the data presentation in the form of excerptions of sentences or utterances taken from Donald Trump's presidential candidacy speeches. The data are going to be classified into the types of Illocutionary acts based on Searle's classification. (3) Verification. In this point, the writer is going to verify or to take conclusion from the data.

Based on the theory above, the researcher do some steps in analyzing the data.

a. Writing some notes of illocutionary acts offered by Searle.

b. Watching as well as reading the transcripts carefully and sorting them by looking for units of words, phrases, and sentences in the Donald Trump's presidential candidacy speeches.

c. Signing up the illocutionary acts contained within the speeches.

d. Analyzing the differences and dominant illocutionary acts used by Donald Trump in his presidential candidacy speeches.

e. Classifying each identified and signed into types of illocutionary acts.

f. Inputting the percentages of the data by using percentage formula of statistical descriptive calculation proposed by Sudjana (1999):

Notation: $\quad \mathrm{P}=$ Percentage

$\mathrm{Fq}=$ Frequency of every indicator

$\mathrm{N}=$ Number of frequency

(Ma'ruf, A., \& Rahim, A., 2013, p.150)

g. Writing the report of the study.

\section{RESEARCH RESULT}

The data findings showed that there were differences in the appearances of each type of illocutionary acts in both Donald Trump's presidential candidacy speeches. In the first speech, Donald Trump produced about $77 \%$ of assertive type of illocutionary acts in his speech. It was followed by the production of $1 \%$ of directive, $18 \%$ of commissive, and $4 \%$ of expressive types of ilocutionary acts in the first Donald Trump's speech. While, in the second speech, Donald Trump produced about $88 \%$ of assertive type of illocutionary acts. It was followed by the production of $8 \%$ of commissive, and 3\% of expressive types of illocutionary acts in the second Donald Trump's speech.

However, each type of illocutionary acts had its own categories. Here, the researcher also identified and classified the different appearance of categories from each type of illocutionary acts.

From the first speech entitled "Donald Trump's Speech on Fighting Terrorism in Youngstown, University of Ohio, on 15th of August 2016", the type of illocutionary acts used were assertive with 127 utterances, it included some categories of illocutionary type such as 56 asserting, 30 describing, 2 complaining, and 10 informing. Then, directive with 1 utterance included into suggesting category. It was followed by commissive with 23 utterances, those are were included

An Analysis Of The Illocutionary Acts On Donald Trump's

Presidential Candidacy Speech

${ }^{1}$ Desinta Larasati, ${ }^{2}$ Arjulayana, ${ }^{3}$ Cut Novita Srikandi 
ISSN: 2301-9913, E-ISSN: 2597-9132

DOI: http://dx.doi.org/10.31000/globish.v7i2

into promising category. Finally, experessive with 5 utterances. It included some categories of illocutionary acts such as 2 thanking, and 3 blaming.

From the second speech entitled "Donald Trump Announces a Presidential Bid: Talking about Current Issues of the Country, Trump Tower, New York City on 15 th of June 2015", the type of illocutionary acts used were assertive with 246 utterances, it included some categories of illocutionary type such as 124 asserting, 101 describing, 5 claiming, 1 complaining, and 15 informing. Then, commissive with 23 utterances. It included some categories of illocutionary type such as 21 promising and 2 vowing. Last but not least, expressive with 9 utterances. It included some categories of illocutionary type such as 8 thanking and 1 praising.

\section{CONCLUSION}

From the data above, we can draw conclusion that the assertive type of illocutionary acts was the most dominant type of illocutionary acts appeared in the Donald Trump's presidential candidacy speeches. While the asserting category was the most dominant category of illocutionary types appeared in the Donald Trump's presidential candidacy speeches.

Searle's theory of speech act revealed that assertives refers to an illocutionary acts represented a state of affair. The assertive type consisted of some assertive categories such as asserting, describing, claiming, complaining, and informing. The assertive acts were performed by speaker or writer to tell about what they knew or believed, it was regardless from truth or false. Thus, the statement could be a real fact or something that the writer or speaker believed was true.

Donald Trump produced more assertive type of illocutionary acts than another type of illocutionary acts in his speeches. If the researcher matched the theory with the result data of Donald Trump's utterances, the most frequently appearances of assertive type of illocutionary acts was due to the fact that Donald Trump produced many of statements which told about facts, or what he knew or believed. So, there was a suitability between the theory and the result of the data.

The declarative type of illocutionary acts did not appear at all in both of Donald Trump's speeches due to the fact that declarative type refers to an illocutionary act that brings into existence the state of affairs of something new such as status, position, and circumstance. Since this act may cause a changing of status, position or condition toward something, the speaker must have specific instutional role or position and there must be specific context as well. Because Donald Trump has not elected and became the president of America, so he could not make any declarations or declarative type of illocutionary acts in his utterances while doing speech.

\section{REFERENCES \\ Books:}

Aitchison, J. (2010). Aitchison's Linguistics. United States: McGraw-Hill Companies. Inc.

Al Hindawi, et. al. (2014). The Speech Act Theory in English and Arabic. Open Journal of Modern Linguistics: Scientific Research. Vol 4. p. 29.

Altikriti, S. Farouq. (2011). Speech Act Analysis to Short Stories. Journal of Language Teaching and Research. Vol 2 (6). p.1.

Asadu, Oluchukwu. (2013). Speech Act Analysis: Hosni Mubarak's Speeches in Pre-crises and Incrises Egypt. Journal of African Studies. Vol 2. p.83.

Austin, J. L. (1962). How to Do Things With Words. London: Oxford University Press.

Baktir, Hasan. (2012). Speech Act Theory; Austin And Searle: Derrida's Response And

Deleuze's Theory Of Order-Word. Military Technical Academy Publishing House. Vol. 5 (2). p. 201.

An Analysis Of The Illocutionary Acts On Donald Trump's

Presidential Candidacy Speech

${ }^{1}$ Desinta Larasati, ${ }^{2}$ Arjulayana, ${ }^{3}$ Cut Novita Srikandi 
ISSN: 2301-9913, E-ISSN: 2597-9132

DOI: http://dx.doi.org/10.31000/globish.v7i2

Bangun, Tara Astika., Daulay. Syahnan., \& Saragi, Daulat. (2017). An Analysis Of The

Illocutionary Act In Indonesia's Meme Comics At Social Media And Its Advantages As Reading Materials For Senior High School. British Journal of English Linguistics. Vol. 5 (4).p. 65-66.

Blutner, Reinhard. (2006). The Handbook of Pragmatics: Pragmatics and the Lexicon. United Kingdom: Blackwell Publishing.

Davidovitch, Nitza., \& Khyzhniak, Kateryna. (2018). Language Personality in the Conditions of Cross-Cultural Communication: Case-Study Experience. International Education Studies. Vol. 11 (2). p. 13.

Fakultas Keguruan dan Ilmu Pendidikan. (2018). Pedoman Penulisan Skripsi: Fakultas Keguruan dan Ilmu Pengetahuan. p.88. Tangerang: University of Muhammadiyah Tangerang.

Green, Georgia M. (2006). The Handbook of Pragmatics: Some Interactions of Pragmatics and Grammar. (p.408). United Kingdom: Blackwell Publishing.

Herman. (2015). Illocutionary Acts Analysis of Chinese in Pematangsiantar. International Journal of Humanities and Social Science Invention.Vol. 5. p. 41.

Horn, Laurence R., \& Ward, Gregory. (2006). Ch. 3: Speech Act. In the Handbook of Pragmatics. (pp. 53-73). Australia: Blackwell Publishing Ltd.

K, Anin Listya., \& Novitasari, Nine Febri. (2015). The Analysis Of Illocutionary Acts In The President Joko Widodo's Speech. Journal of Illocutionary Acts. Vol. 5. p. 118.

Leech, Geoffrey. N. (2014). The Pragmatics of Politeness. p. 89. New York: Oxford University Press.

Mey, J. L. (2001). Pragmatics: an Introduction. Second Edition. United Kingdom: Blackwell Publishing.

Praditya, Dwi Jaya., Made, Putra., Adi Jaya., Nyoman., \& Artini, Luh Putu. (2014). An Analysis Of Speech Acts In The Conversation Between Habibie And Ainun In The Film Entitled Habibie and Ainun 2012. e-Journal Program Pascasarjana Universitas Pendidikan Ganesha. Vol. 2. p. 2.

Schriffin, Deborah., Tannen, Deborah., \& Hamilton, E. Heidi. (2001). The Handbook of Discourse Analysis. p. 59. Oxford: Blackwell Publishers Ltd.

Searle, J. R. (1976). Expression and Meaning: Studies in the Theory of Speech Acts. United States: Cambridge University Press.

Simon, Simona., \& Cartis, D. Dejica. (2015). Speech Acts in Written Advertisements: Identification, Classification and Analysis. Elsevier Journal. p. 235.

Tavakoli, Hossein. (2012). A dictionary of Research Methodology and Statistics in Applied Linguistics. p. 358. Iran: Rahnama Press.

Tavakoli, Hossein. (2012). A dictionary of Research Methodology and Statistics in Applied Linguistics. p. 358. Iran: Rahnama Press.

Umar, T. Fahmi. (2016). The Analysis of Speech Act of President Joko Widodo at APEC Forum. p. 1417. Makassar: ALAUDDIN STATE ISLAMIC UNIVERSITY.

Ummah, Muslmatul. (2016). An Analysis of Illocutionary Acts in English Version of the Noble Qur'an Chapter Al Alaq Translated by M. Muhsin Khan and M. Taqi-ud-din Al-hilali. p.48. Tangerang: University of Muhammadiyah Tangerang.

Yule, G. (2010). The Study of Language. p. 133. Cambridge: Cambridge University Press.

\section{Websites:}

Dylgjeri, Ardita. (2017). Analysis of Speech Acts in Political Speeches. p.21-22. Retrieved on December, 3, 2018. https://oapub.org/soc/index.php

Kaburise, P. Koryoo. (2005). Speech Act Theory And Communication: A Univen Study. p.17. Retrieved on November. 26, 2018.

https://www.pdfdrive.com/speevh-act-theory-and-communication-university-ofe14489062.html

Ma'ruf, A., \& Rahim, R. (2013). Increasing Student's Speaking Ability through Bamboo Dancing Method. Vol 2 (2). p. 150. Retrieved on December, 26, 2018.

An Analysis Of The Illocutionary Acts On Donald Trump's

Presidential Candidacy Speech

${ }^{1}$ Desinta Larasati, ${ }^{2}$ Arjulayana, ${ }^{3}$ Cut Novita Srikandi 
ISSN: 2301-9913, E-ISSN: 2597-9132

DOI: http://dx.doi.org/10.31000/globish.v7i2

http://media.neliti.com/media/publications/224496-increasing-the-students-speakingability-f8463b0.pdf

Mubarok, Faiz. (2016). A Pragmatics Analysis of Speech Act in Interrogative Utterances of Surah Al Mulk. A Graduating Paper. p.12-13. Retrieved on December, 3, 2018.

https://e-repository.perpus.iainsalatiga.ac.id/775/1/Faiz\%2520Mubarok\%2520 \%2520Graduating\%2520Paper.pdf

Mudzakir, Ahmad. (2013). A Speech Act Analysis of Direct Utterances on Short Story Mr. Know All. p.4. Retrieved on October, 28, 2018. https://eprints.ums.ac.id/22965/16/PUBLICATION JOURNAL.pdf

Nugroho, A. Suryo. (2011). An Analysis of Illocutionary Acts in Sherlock Holmes Movie. p.8. Retrieved on October, 28, 2018.

https://www.beaconsociety.com/uploads/3/7/8/37380505/nugroho agung an analys is of illocutionary acts in sherlock holmes movie.pdf

Rahma, A. Nurulita. (2013). Analisis Tindak Tutur Ilokusi dalam Dialog Film Animasi Meraih Mimpi. Vol 2 (2). p.16. Retrieved on December, 10, 2018.

http://journal.unair.ac.id/download-fullpapers-skriptorium184a7bf7d4full.pdf

Saputro, E. P. Nugroho. (2015). The analysis of Illocutionary Acts of Jokowi's Speeches. Retrieved on October, 28, 2018, from source Web: http://repository.usd.ac.id/3950/2/126332012 full.pdf

Sani, I. Fajri., Rina, Nova., \& Tanjung, Fatimah. (2013). An Analysis of Illocutionary Act Found in Food and Beverage Advertisements. Vol 2 (2). Retrieved on October, 28, 2018. https://www.ejournal.bunghatta.ac.id/index.php?journal=JFIB\&page=article\&op=view \&path

Usman, F. Rahmawati. (2017). An Analysis of Illocutionary Acts in Donald Trump's Presidential Candidacy Speech. p.12-13. Retrieved on October, 28, 2018. https://digilib.unhas.ac.id/uploaded files/temporary/DigitalCollection/

Wardani, N. Azni. (2011). An Analysis of Illocutionary Act in Prince of Persia: The Sand of Time Movie. p.3. Retrieved on October, 28. 2018.

https://repository.uinjkt.ac.id/dspace/handle/123456789/3

An Analysis Of The Illocutionary Acts On Donald Trump's

Presidential Candidacy Speech

${ }^{1}$ Desinta Larasati, ${ }^{2}$ Arjulayana, ${ }^{3}$ Cut Novita Srikandi 